\title{
FACTORS ASSOCIATED WITH DEVELOPMENT DISORDER IN CHILDREN 4-5 YEARS OF AGE
}

\author{
Eny Qurniyawati \\ School of Health Sciences Bhakti Husada Mulia, Madiun, East Java
}

\begin{abstract}
Background: Child development disorder can have long-term deleterious impacts in future. The purpose of this study was to examine factors associated with child development disorder.

Subjects and Method: This was an analytic observational study using case control design. The study was conducted at Bantengan Village Playing Group, Madiun, East Java, in May 2017. A sample of 32 children aged 4-5 years and their mothers were selected for this study by purposive sampling. Cases were children with development disorder. Controls was children with normal development. The dependent variable was development status, including fine and coarse, language, and social development. The independent variables were maternal age, maternal education, and number of children. The data were collected by questionnaire and analyzed by multiple logistic regression.

Results: Child development disorder was associated with maternal age $\geq 35$ or $<20$ years $(\mathrm{OR}=51.55 ; 95 \% \mathrm{CI}=1.37$ to $193.93 ; \mathrm{p}=0.033)$, low maternal education $(\mathrm{OR}=19.88 ; 95 \% \mathrm{CI}=1.01$ to $390.58 ; \mathrm{p}=0.049)$, and number of children >2 (OR: $24.49 ; 95 \% \mathrm{CI}=1.37$ to $438.04 ; \mathrm{p}=0.030)$.
\end{abstract}

Conclusion: Child development disorder is associated with maternal age $\geq 35$ or $<20$ years, low maternal education, and number of children $>2$.

Keywords: development disorder, risk factors, children

Correspondence: Eny Qurniyawati. School of Health Sciences Bhakti Husada Mulia, Madiun, East Java. Email: enyqur88@gmail.com.

Mobile: +6285727718700. 